\section{PRODUCTION}

ENGINEERING ARCHIVES
2016, Vol. 12, No. 3, pp 2-4

ISSN 2353-5156

ISSN 2353-7779 (print version)

(online version)

\title{
Analysis of FRP bars used as reinforcement in concrete structures
}

\author{
Kinga Brózda ${ }^{1}$, Jacek Selejdak ${ }^{2}$ \\ ${ }^{1}$ Czestochowa University of Technology, The Faculty of Civil Engineering, Department of Building Structures and Engineering, \\ Akademicka 3, 42-200 Czestochowa, Poland, brozda.kinga@gmail.com \\ ${ }^{2}$ Czestochowa University of Technology, The Faculty of Civil Engineering, Department of Building Structures and Engineering, \\ Akademicka 3, 42-200 Czestochowa, Poland, jaceksel@ poczta.onet.pl
}

\begin{abstract}
In the design and construction of building and engineering structures, it is of utmost importance to provide their reliability and safety. The use of FRP (Fiber Reinforced Polymers) bars as reinforcement of structural concrete elements could help reducing the typical defects of reinforced concrete and increase its strength parameters. In the paper the selected FRP bar characteristic properties are presented and advantages derived therefrom are specified. Furthermore, the most commonly used in construction types of FRP bars, depending on the raw material used during the production process are listed. In addition, the possibility of recycling of elements reinforced with FRP bars is presented and compared with traditional reinforced concrete (reinforced with steel bars). The production method of FRP bars (pultrusion) is shown. Moreover, the advantages and disadvantages of using this method are discussed.
\end{abstract}

Key words - Fiber Reinforced Polymers, reinforcement, concrete, characteristic properties, production process, pultrusion

\section{Introduction}

The most important requirements concerning building and engineering structures include ensuring reliability and safety. According to the applicable standard Eurocode (EN 1990: 2002) both these requirements should be provided not only during implementation, but duringthe whole time of existence of the structure. The reliability and safety of the structure are specified depending on its function and the place of its achievement. In accordance with the theory of limit states, during the assumed time of operation of the facility, and depending on its defined operating conditions, it is unacceptable to exceed the ultimate limit states (ULS) or serviceability limit states (SLS) (BASZKIEWICZ K., SELEJDAK J. 2014, BRÓZDA K.,
SELEJDAK J. 2015, RUNKIEWICZ L. 1999). At present, in the construction industry two structural materials dominate, namely steel and concrete. However, rapid advances in technology allows to introduce new structural solutions in the construction sector increasingly. Nowadays composite materials are an attractive alternative to traditional building materials. In the view of developments in the availability, those materials are used progressively. Composites are used not only as piece of equipment, but also as structural elements or internal reinforcement of concrete structures. Moreover, composite materials partially reduce the limitations of traditional structural materials, relating to the strength parameters or assembly difficulties (BASZKIEWICZ K., SEleJdaK J. 2015, SEleJdaK J., BRÓZDA K. 2016). 


\section{Composite materials as reinforcement in structuralconcrete elements}

One of the ways of improving the strength parameters of structural concrete elements is the use of reinforcement in the tension zone. The resulting material (reinforced concrete) combines the advantages of its constituent materials. Steel is typical reinforcing material, used as rods (MADAJ A., WOŁOWSKI W. 2002).

The alternative solution for the traditional steel reinforcement, which solves many problems (e.g. resulting from the corrosion), are FRP (Fibre Reinforced Polymer) bars. Depending on the raw material used during the production process, there are four basic types of FRP bars (BASZKIEWICZ K., SELEJDAK J. 2015, REJMENT M., TRAPKO T. 2014):

- Glass Fiber Reinforced Polymers (GFRP),

- Carbon Fiber Reinforced Polymers (CFRP),

- Aramid Fiber Reinforced Polymers (AFRP),

- Basalt Fibre Reinforced Polymer (BFRP).

The FRP bars are characterized by a number of very good properties, which are shown in Table 1. Furthermore, utilization of those bars is far easier than that of traditional reinforced concrete, where before reuse it is necessary to separate the reinforcement from concrete.This extraction is important especially when the material is classified as hazardous waste (KLIMECKA-TATAR D. 2015). It is impossible to reuse the reinforced steel if polluted concrete is left. In the case of recycling concrete elements reinforced with FRP bars, it is possible to crush concrete with reinforcement - there is no need to extract the reinforcement from concrete (BRÓZDA K., SELEJDAK J. 2015, SELEJDAK J., BRÓZDA K. 2016).

\section{Production process}

A suitable production process of the composite materials, i.e. the proper connection between the resin matrix and fiber reinforcement, is a condition for obtaining the appropriate material properties. The special production process ensures total impregnation of the fibres and a very high degree of curing. In order to obtain the optimum strength parameters, the pultrusion method is used to produce FRP bars.
(BASZKIEWICZK., SELEJDAK J. 2015). The schematic of production process of FRP bars is shown in Fig. 1.

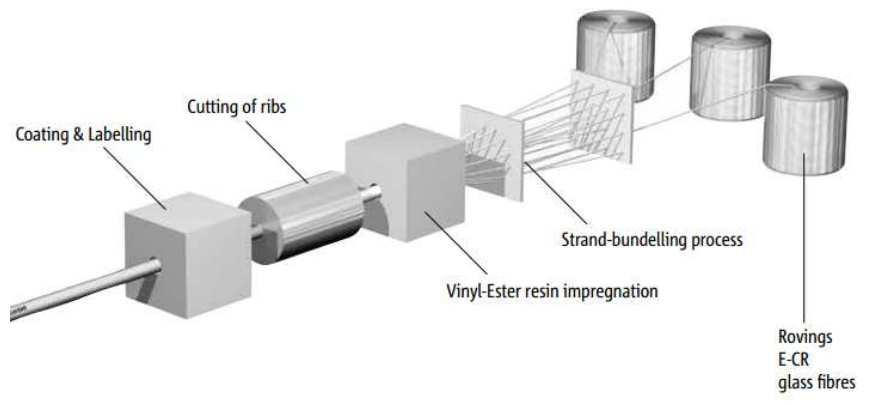

Fig. 1. Schematic of the production process(pultrusion) of FRP bars

Source: study based on Schöck ComBAR - Technical Information, 10/20/2016

Table 1. The FRP bars characteristic properties and attendant advantages.

\begin{tabular}{|c|c|}
\hline $\begin{array}{c}\text { Characteristic } \\
\text { properties }\end{array}$ & Advantages \\
\hline High tensile strength & $\begin{array}{l}\text { - Possibility to reduce the diameter } \\
\text { of the bars, } \\
\text { - Reduction of the dead load }\end{array}$ \\
\hline $\begin{array}{l}\text { High resistance to the } \\
\text { corrosion }\end{array}$ & $\begin{array}{l}\text { - Increased durability, } \\
\text { - Possibility to reduce the concrete } \\
\text { cover, } \\
\text { - No need to perform frequent } \\
\text { maintenance and repairs }\end{array}$ \\
\hline $\begin{array}{l}\text { Very low thermal con- } \\
\text { ductivity }\end{array}$ & - Reduction of heat loss \\
\hline $\begin{array}{l}\text { Electromagnetically, } \\
\text { electrically and electros- } \\
\text { tatically neutral }\end{array}$ & $\begin{array}{l}\text { - It does not cause disruptions (e.g. } \\
\text { during industrial equipment } \\
\text { work), } \\
\text { - The ability to assembly in areas } \\
\text { exposed to the effects of electro- } \\
\text { magnetic fields. }\end{array}$ \\
\hline $\begin{array}{l}\text { Similar coefficient of } \\
\text { thermal expansion of } \\
\text { concrete and FRP bars }\end{array}$ & $\begin{array}{l}\text { - Reduced risk of reinforcement } \\
\text { and concrete damages under the } \\
\text { influence of temperature changes }\end{array}$ \\
\hline Low density & $\begin{array}{l}\text { - lightness, } \\
\text { - easy transportation, } \\
\text { - facilitation of reinforcing process }\end{array}$ \\
\hline
\end{tabular}

Source: study based on (SELEJDAK J., BRÓZDA K. 2016),(REJMENT M., TRAPKO T. 2014) 
Tapes, which consist of a bundle of parallel fibers, are pre-bonded together by a sticky substance around the rovings. Next, expanded tape is placed in a tub filled with a thermosetting resin. Fiber bundles prepared in such a way are pulled through a special extruder to cut the ribs. When the element has the final shape, bar is coated and impregnated by synthetic resin. The production speed in this method reaches up to several tens of meters per hour (BASZKIEWICZ K., SELEJDAK J. 2015, JAREK B., KUBIK A. 2015).

In pultrusion method only straight bars are produced - there is no possibility of obtaining curved elements. For example, stirrups are produced by using a polypropylene pipe, which is filled with reinforcement (fibers) and matrix (resin). After obtaining desired shape, thermal curing follows. This method allows to obtain high strength parameters comparable to straight bars (BASZKIEWICZ K., SELEJDAK J. 2015).

\section{Summary}

It is necessary to ensure reliability and safety; during designing and realization building and engineering structures. The appropriate structural and material solutions are considered as early as at the design stage. Those solutions include reduction of dead load of the structure, while the large load capacity is maintained, or, furthermore, the parameters of the permissible load (capacity) are increased. In order to achieve increasing strength parameters of reinforced concrete it is possible to use FRP bars as reinforcement of structural concrete elements.

The FRP bars are characterized by very good properties and much easier recycling in comparison with traditional reinforced concrete. Good strength parameters result from the proper production method pultrusion. High strength fibers are pulled out through closed chamber,where subsequently are impregnated with a synthetic resin. The pultrusion method is useful only in straight bars production. This method allows to obtain the best results in the production of highstrength materials used for reinforcement of concrete. Moreover, the production speed in pultrusion methodreaches up to tens of meters for one hour, which can lead to the dissemination of the method and falling prices of the finished product.

\section{Literature}

1. Baszkiewicz K., Selejdak J. 2014. Comparison of selected properties of reinforced concrete and prestressed concrete structures for bending structural components. Chapter 14, in: Toyotarity. Management of Technology. Aeternitas Publishing House. Alba Iulia.

2. BASZKIEWICZ K., SElEJDAK J. 2015. The use of selected composite materials in the bridges structures. Chapter 3, in: Wybrane interdyscyplinarne zagadnienia budownictwa, red. Nagórski R., Oficyna Wydawnicza Politechniki Warszawskiej. Warszawa. (Zastosowanie wybranych materiatów kompozytowych $w$ konstrukcjach mostowych)

3. BRózDA K., SElEJDAK J. 2015. The issue of wooden and concrete railway sleepers utilization. Vol. 9 No. 4 Production Engineering Archives.

4. EN 1990: 2002. Eurocode: Basis of structural design. (PN-EN 1990: 2004. Eurokod: Podstawy projektowania konstrukcji)

5. JAREK B., KUBIK A. 2015. The use of rebar reinforced with fiberglass (GFRP) in construction industry. No. 12 Przegląd budowlany. (Zastosowanie prętów zbrojeniowych z włókna szklanego (GRFP) w budownictwie)

6. KlimeCKA - TATAR D. 2015. Safety restrictions in the logistics of dangerous and toxic substances. Vol.7 No.2 Production Engineering Archives.

7. Madaj A., Wołowski W. 2002. Concrete brigdes. Wydawnictwo komunikacji i łączności sp. z o.o. Warszawa. (Mosty betonowe)

8. SELEJDAK J., BRÓZDA K. 2016.Composite materials in Sustainable Civil Engineering. Chapter 9, in: Wybrane zagadnienia inżynierii środowiska w budownictwie. Polski Związek Inżynierów i Techników Budownictwa, Oddział Opole. Opole.(Zastosowanie kompozytów w budownictwie zrównoważonym)

9. Schöck products catalog, Schöck ComBAR - Technical Information, 10/20/2016

10. RejMent M., Trapko T. 2014.Composite bars for concrete reinforcement. No. 3 Materiały budowlane.(Pręty kompozytowe do zbrojenia betonu)

11. RUNKIEWICZ L. 1999. Diagnosis and strengthening of reinforced concrete structures. Wydawnictwo Politechniki Świętokrzyskiej. Kielce. (Diagnostyka i wzmacnianie konstrukcji żelbetonowych) 